\title{
Mutations in SRY and WT1 genes required for gonadal development are not responsible for $\mathrm{XY}$ partial gonadal dysgenesis
}

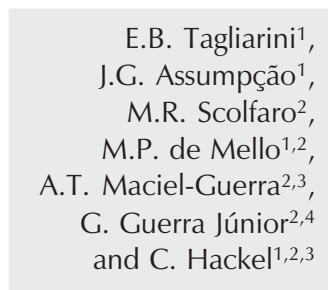

\author{
${ }^{1}$ Centro de Biologia Molecular e Engenharia Genética (CBMEG), \\ ${ }^{2}$ Grupo Interdisciplinar de Estudos da Determinação e Diferenciação do Sexo \\ (GIEDDS), and Departamentos de ${ }^{3}$ Genética Médica, and ${ }^{4}$ Pediatria, \\ Faculdade de Ciências Médicas, Universidade Estadual de Campinas, \\ Campinas, SP, Brasil
}

\section{Correspondence \\ C. Hackel \\ Departamento de Genética Médica \\ Faculdade de Ciências Médicas \\ UNICAMP \\ Rua Tessália Vieira de Camargo, 126 \\ Caixa Postal 6111 \\ 13084-971 Campinas, SP \\ Brasil \\ Fax: +55-19-3788-8909 \\ E-mail: hackel@unicamp.br \\ Research supported by grants to \\ C. Hackel from the Fundo de Apoio \\ ao Ensino e à Pesquisa da UNICAMP \\ (FAEP-UNICAMP). E.B. Tagliarini and \\ J.G. Assumpção were recipients of \\ postgraduate fellowships from CAPES \\ and $\mathrm{CNPq}$, respectively.}

Publication supported by FAPESP.

Received April 5, 2004

Accepted November 23, 2004

.................

\section{Abstract}

The WTI transcription factor regulates $S R Y$ expression during the initial steps of the sex determination process in humans, activating a gene cascade leading to testis differentiation. In addition to causing Wilms' tumor, mutations in WT1 are often responsible for urogenital defects in men, while $S R Y$ mutations are mainly related to 46 ,XY pure gonadal dysgenesis. In order to evaluate their role in abnormal testicular organogenesis, we screened for $S R Y$ and $W T 1$ gene mutations in 10 children with XY partial gonadal dysgenesis, 2 of whom with a history of Wilms' tumor. The open reading frame and $360 \mathrm{bp}$ of the $5^{\prime}$ flanking sequence of the $S R Y$ gene, and the ten exons and intron boundaries of the WT1 gene were amplified by PCR of genomic DNA. Single-strand conformation polymorphism was initially used for WT1 mutation screening. Since shifts in fragment migration were only observed for intron/exon 4, the ten WTl exons from all patients were sequenced manually. No mutations were detected in the $S R Y 5^{\prime}$ untranslated region or within $S R Y$ open-reading frame sequences. $W T 1$ sequencing revealed one missense mutation (D396N) in the ninth exon of a patient who also had Wilms' tumor. In addition, two silent point mutations were found in the first exon including one described here for the first time. Some non-coding sequence variations were detected, representing one new (IVS4 $+85 \mathrm{~A}>\mathrm{G}$ ) and two already described (-7ATG T $>\mathrm{G}$, IVS9-49 $\mathrm{T}>\mathrm{C}$ ) single nucleotide polymorphisms. Therefore, mutations in two major genes required for gonadal development, $S R Y$ and $W T 1$, are not responsible for XY partial gonadal dysgenesis.
Key words - XY partial gonadal dysgenesis

- SRY open reading frame

- SRY 51 untranslated region

- WT1 exons

- Denys-Drash syndrome 


\section{Introduction}

$\mathrm{XY}$ gonadal dysgenesis is a disorder of sexual determination and differentiation that includes a complete (pure) and a partial form. Patients with a 46,XY karyotype and pure gonadal dysgenesis have a female phenotype with full development of unambiguous female genitalia, well-developed Müllerian structures and streak gonads. In contrast, patients with 46,XY partial gonadal dysgenesis are characterized by partial testicular differentiation, low levels of testosterone, ambiguous genitalia, and persistence of Müllerian structures. Patients with both forms are at increased risk for gonadal neoplastic transformation (1). Depending on the severity of testicular dysgenesis, anti-Müllerian hormone levels may be low or undetectable in patients with abnormal testicular determination $(2,3)$. Gonadal histology is typically characterized by poorly developed seminiferous tubules surrounded by wavy ovarian stroma, but may range from apparently normally differentiated testes to streak gonads. According to Berkovitz et al. (4), patients with $46, X Y$ partial gonadal dysgenesis may present a wide range of characteristics depending on the extent of testicular development and they may have either bilateral dysgenetic testes or one dysgenetic testis and one streak gonad. Scolfaro et al. (5) described this histological variability in a series of 13 children with partial gonadal dysgenesis.

Sex-determining genes direct the fate of the bipotential gonad to either testis or ovary. They can be categorized into transcription factors involved throughout gonadal morphogenesis (e.g., $S F 1, W T 1$ ), inducers of testicular development (SRY, SOX9), and "anti-testis" genes and potential promoters of ovarian development (DAX1, WNT4). All of these genes are expressed in the developing genital ridges, and their products interact with each other as part of a complex genetic pathway leading to gonadal differentiation into one sex or the other (6).

Mutations in or abnormal expression of any of such genes will impair the formation of testes in an XY background or the formation of ovaries in an XX background (6). Indeed, mutations in the $S R Y$ (sex determining region on the $\mathrm{Y}$ chromosome), the major gene required for male sex determination, have been reported to account for 20 to $67 \%$ of cases of 46,XY pure gonadal dysgenesis (7). In most cases the mutations are located within the high mobility group box, which is a DNA-binding domain essential for SRY function as a transcriptional regulator. Only seven SRY mutations of the 44 described so far are found outside this domain (8). Nucleotide changes in the 5 ' untranslated region (UTR) flanking sequence of the $S R Y$ gene seem not to be a major cause of disturbance in the male differentiation pathway but a few mutations that might affect $S R Y$ expression have been reported in XY females (9).

WT1 (Wilms' tumor gene 1) encodes a transcription factor containing four "zincfinger" motifs which binds to and acts synergistically with SRY to activate transcription from promoters containing SRY-binding sites (10), being also required for the normal development and function of the urogenital tract $(11,12)$. The complexity of WT1 action is reflected at the molecular level, since up to 24 different isoforms may result from a combination of alternative translational sites, alternative RNA splicing and RNA editing (13). Constitutional mutations are associated with familial Wilms' tumor and syndromes such as Denys-Drash syndrome characterized by nephropathy, genital anomalies and often a predisposition to Wilms' tumor (12). Transcripts of the WT1 gene are detected in the gonadal ridge as early as 6 weeks postconception in human embryos, before testis determination (14). According to Fuqua et al. (15), mutations in the WT1 gene may result in abnormalities of gonadal ridge formation that delay testis determination. Since the $W T 1$ gene is also expressed in 
the gonadal ridge after testis determination (14), defects in WT1 may also delay the differentiation after SRY expression.

In this report, we present the data obtained for 10 patients with a diagnosis of partial gonadal dysgenesis who were investigated for mutations in the SRY and WTI coding and non-coding sequences.

\section{Patients and Methods}

The series consisted of 10 patients with a diagnosis of partial gonadal dysgenesis and a 46,XY karyotype. They were examined by the members of the Grupo Interdisciplinar de Estudos da Determinação e Diferenciação do Sexo at Hospital das Clínicas, Universidade Estadual de Campinas (UNICAMP), Campinas, SP, Brazil. The protocol was approved by the Ethics Committee of Faculdade de Ciências Médicas, UNICAMP. Informed consent was obtained from the parents of the children included in the study.

The diagnosis of XY partial gonadal dysgenesis was based on findings of ambiguous genitalia and bilateral cryptorchidism, low levels of testosterone and anti-Müllerian hormone (Table 1). All patients showed evidence of Müllerian duct derivatives, which was confirmed by laparoscopy.

Patients 9 and 10 had a personal history of unilateral Wilms' tumor. Patient 10 also had progressive renal failure and died at 13 months of age; at autopsy, kidney evaluation revealed diffuse mesangial sclerosis. This patient had a Denys-Drash syndrome phenotype. No patient had a family history of intersex.

The diagnosis of gonadal dysgenesis was confirmed by a careful histologic and morphometric evaluation of the gonads based on the following criteria: gonadal position, mean tubular diameter, number of germ cells, number of Sertoli cells, and presence or absence of Müllerian and Wolffian duct derivatives. These results were published in a report by Scolfaro et al. (5), in which the present patients 1 to 9 were patients $2,3,4,6,7,8,9$, 13 , and 12 , respectively. At autopsy, bilateral streak gonads were found in patient 10 .

Genomic DNA was extracted from peripheral blood leukocytes by standard techniques (17). The $S R Y$ open reading frame (ORF) was amplified with primers XES10

\begin{tabular}{|c|c|c|c|c|c|c|c|}
\hline Patient & $\begin{array}{c}\text { Age } \\
\text { (months) }\end{array}$ & $\begin{array}{l}\text { External } \\
\text { genitalia }{ }^{1}\end{array}$ & $\begin{array}{l}\text { Gonadal position } \\
\text { (right/left) }\end{array}$ & $\begin{array}{l}\text { AMH (normal values } \\
\text { for age) (pmol/l) }\end{array}$ & $\begin{array}{c}\mathrm{T} \\
(\mathrm{nmol} /)^{2}\end{array}$ & $\begin{array}{l}\mathrm{FSH} \\
(\mathrm{IU} /)^{3}\end{array}$ & $\begin{array}{l}\mathrm{LH} \\
(\mathrm{IU} /)^{4}\end{array}$ \\
\hline 1 & 108 & 2 & A/A (left = streak) & $114(234-438)$ & 0.7 & 5.4 & 0.9 \\
\hline 2 & 30 & 2 & |// & 52 (360-638) & $<0.3$ & 1.2 & 0.6 \\
\hline 3 & 0.5 & 3 & $1 / 1$ & 98 (251-679) & $1.7^{5}$ & 3.9 & 0.8 \\
\hline 4 & 92 & 2 & I/A (left = streak) & $113(234-438)$ & $<0.3$ & 5.8 & 0.8 \\
\hline 5 & 78 & 2 & |/- & 73 (309-566) & 1.0 & 6.3 & 1.0 \\
\hline 6 & 13 & 2 & $1 / /$ & 107 (360-638) & $<0.3$ & 1.0 & 0.5 \\
\hline 7 & 20 & 4 & I/A (left = streak) & $11(360-638)$ & $<0.3$ & 1.5 & 1.1 \\
\hline 8 & 44 & 3 & I/A (left = streak) & 71 (360-638) & $<0.3$ & 0.9 & 0.9 \\
\hline 9\# & 29 & 3 & $\mathrm{~A} / \mathrm{A}$ & $116(360-638)$ & 3.1 & 0.7 & 0.3 \\
\hline $10 \#$ & 12 & 2 & I/A & NP & $<0.3$ & 7.8 & 3.4 \\
\hline
\end{tabular}

$\mathrm{AMH}=$ anti-Müllerian hormone (2); $\mathrm{T}=$ total testosterone; $\mathrm{FSH}=$ follicle-stimulating hormone; $\mathrm{LH}=$ luteinizing hormone; $A=$ abdominal; $\mid$ = inguinal canal; - , not found; NP = not performed.

${ }^{1}$ According to the classification of Quigley et al. (16). ${ }^{2}$ Total testosterone level after the human chorionic gonadotropin stimulation test (normal value: above $1.4 \mathrm{nmol} / \mathrm{l}) .{ }^{3}$ Normal values of prepubertal FSH: $0.1-1.4$ IU/I. ${ }^{4}$ Normal values of prepubertal LH: 0.1-1.0 IU/I. ${ }^{5}$ Basal total testosterone level. \#Patient with a past history of Wilms' tumor. 
and XES11 described by Hawkins et al. (18). PCR amplifications were performed by the method of Assumpção et al. (8). For the amplification of the 360-bp SRY 5' flanking sequence, encompassing the $S R Y$ putative core promoter, we used the primers and PCR conditions described by Schmitt-Ney et al. (19). Five microliters of PCR amplification products were submitted to direct sequencing with the Thermo-sequenase radiolabeled terminator cycle sequencing kit (AmershamPharmacia Biotech, Uppsala, Sweden). Sequencing was carried out twice with products from different PCR procedures and with both sense and antisense primers to confirm the results.

The 10 exons and their flanking regions of the WT1 gene were amplified by PCR from genomic DNA with primers described in Table 2. Due to its long size and some difficulties in fragment amplification, 3 dif- ferent primer pairs were used for exon 1 . The PCR amplifications were performed as described before for $S R Y(8)$, except that DMSO was omitted. After a first denaturation step $\left(10 \mathrm{~min}, 95^{\circ} \mathrm{C}\right)$, the cycling profile was: $95^{\circ} \mathrm{C}$, $1 \mathrm{~min} ; 54-64^{\circ} \mathrm{C}, 1 \mathrm{~min} ; 72^{\circ} \mathrm{C}, 1 \mathrm{~min}(30$ cycles), followed by $10 \mathrm{~min}$ at $72^{\circ} \mathrm{C}$ (final extension). The PCR products were analyzed in $1 \%$ ethidium bromide-stained agarose gels to determine the size of the fragments. Amplified products were screened for sequence variations by non-radioactive single-strand conformation polymorphism (SSCP) analysis. Electrophoresis was performed with the PhastSystem ${ }^{\mathrm{TM}}$ (Pharmacia Biotech) using 12.5 and 20\% non-denaturing polyacrylamide homogeneous Phastgel with PhastGel SDS and native buffer strips and the gels were silver stained. Direct sequencing of PCR products was carried out in two separate reactions using sense and anti-

Table 2. Primers designed for WT1 amplification.

\begin{tabular}{|c|c|c|c|c|c|}
\hline Exon & Sequences 5'-3' & (nt positions) & $\begin{array}{c}\text { Annealing } \\
\text { temperature }\left({ }^{\circ} \mathrm{C}\right)\end{array}$ & $\begin{array}{l}\text { Size } \\
\text { (bp) }\end{array}$ & $\begin{array}{c}\text { GenBank accession } \\
\text { number }\end{array}$ \\
\hline \multirow[t]{6}{*}{1} & 1S - AGCCAGAGCAGCAGGGAGT & $(665-683)$ & 64 & 278 & X61631 \\
\hline & 1AS - ACGACCCGTAAGCCGAAGC & $(922-940)$ & & & \\
\hline & 1BS - ATGGGCTCCGACGTGC & $(790-805)$ & 54 & 215 & \\
\hline & 1BAS - ATGAAGGAGTGAGGCGG & (988-1004) & & & \\
\hline & 1CS - TTCGGCTTACGGGTCGTTGG & (924-943) & 62 & 397 & \\
\hline & 1CAS - CAAAAGGGGTAGGAGAGGGG & (1301-1320) & & & \\
\hline \multirow[t]{2}{*}{2} & 2S - CCGTCTTGCGAGAGCACC & $(3-20)$ & 58 & 262 & M80218 \\
\hline & 2AS - CTAATTTGCTGTGGGTTAGG & $(245-264)$ & & & \\
\hline \multirow[t]{2}{*}{3} & 3S - GCTCAGGATCTCGTGTCTCC & $(5-24)$ & 64 & 318 & M80219 \\
\hline & 3AS - GCCTCCAAGACCCAGCAT & $(305-322)$ & & & \\
\hline \multirow[t]{2}{*}{4} & 4S - CAGTTGTGTATTATTTTGTGG & $(235-255)$ & 56 & 285 & X61633 \\
\hline & 4AS - AACTAGGGGAAGGAGGAAA & $(502-520)$ & & & \\
\hline \multirow[t]{2}{*}{5} & 5S - ССАСТССССАССТСТTС & $(190-206)$ & 56 & 115 & X61634 \\
\hline & 5AS - CGCCATTTGCTTTTGCC & $(290-305)$ & & & \\
\hline \multirow[t]{2}{*}{6} & 6S - CCTTTTTCССTTCTTTG & $(159-175)$ & 52 & 179 & X61635 \\
\hline & 6AS - TAAGTAGGAAGAGGCAGT & (320-337) & & & \\
\hline \multirow[t]{2}{*}{7} & 7S - GCTTAAAGCCTCCСTTC & $(157-173)$ & 54 & 231 & X61636 \\
\hline & 7AS - CTTGAACCATGTTTGCCC & (370-387) & & & \\
\hline \multirow[t]{2}{*}{8} & 8S - GAGATCCCCTTTTCCAG & $(178-194)$ & 56 & 177 & X61637 \\
\hline & 8AS - CACAGCTGCCAGCAATG & (338-354) & & & \\
\hline \multirow[t]{2}{*}{9} & 9S - CTCACTGTGCCCACATTG & (868-885) & 58 & 210 & X61637 \\
\hline & 9AS - CAATTTCATTCCACAATAG & (1059-1077) & & & \\
\hline \multirow[t]{2}{*}{10} & 10S - ACTTCACTCGGGCCTTGATAG & (149-169) & 62 & 276 & X61638 \\
\hline & 10AS - AGTGGAGAGTCAGACTTGAAAG & $(403-424)$ & & & \\
\hline
\end{tabular}

$\mathrm{nt}=$ nucleotide; $\mathrm{bp}=$ base pairs . 
sense primers as described above.

\section{Results}

The patients with 46,XY partial gonadal dysgenesis did not present any mutation within the SRY 5' UTR or the SRY ORF sequence, whereas SSCP analysis of the WTI gene revealed shifts only for the fragments obtained with primers $4 \mathrm{~S}$ and $4 \mathrm{AS}$. After sequencing, it was concluded that the shifts observed in the SSCP gels arose as a result of a non-described nucleotide variation in the 3 ' flanking region of the fourth exon, located within intron 4 (IVS4 $+85 A>G$ ). Since the SSCP technique was unable to detect sequence variations in the majority of amplified fragments, sequencing of the whole WT1 coding region was performed. This procedure revealed three single nucleotide polymorphisms (SNPs) already described in normal populations (20) (rs22344582, rs1799925 and rs1799937 according to the Single Nucleotide Polymorphism Database) and a new $163 \mathrm{G}>\mathrm{A}$ silent point mutation at codon 54 (Pro54Pro; patients 3, 5 and 8). Table 3 shows the patients' genotypes for these polymorphic sites. The only pathogenic mutation in this study was a nucleotide change $(1186 \mathrm{G}>\mathrm{A})$, which was found in heterozygous condition in patient No. 10. This transition is located within the ninth exon and causes a missense mutation which changes the predicted aspartic acid in codon 396 to asparagine (D396N).

\section{Discussion}

The absence of SRY mutations observed in the present study reinforces previous literature data which suggest that $S R Y$ mutations in patients with partial gonadal dysgenesis are much less frequent than in XY pure gonadal dysgenesis (22). Among the 44 different SRY ORF mutations reported to date, only three were associated with XY partial gonadal dysgenesis (reviewed by Assumpção et al., 8). One of them was a variant sequence $(\mathrm{S} 18 \mathrm{~N})$ also found in normal relatives of the patient (23). The second (R30I) was found in affected and non-affected members of a family, including the father, two siblings with partial gonadal dysgenesis, a phenotypic female with pure gonadal dysgenesis, and three

Table 3. WT1 single nucleotide polymorphism genotypes in 10 children with partial gonadal dysgenesis

\begin{tabular}{|c|c|c|c|c|c|}
\hline \multirow[t]{2}{*}{ Patient } & \multicolumn{3}{|c|}{ Exon 1} & \multirow{2}{*}{$\begin{array}{c}\text { Intron } 4 \\
+85 \\
23840228^{2} \\
A>G\end{array}$} & \multirow{2}{*}{$\begin{array}{c}\text { Intron } 9 \\
-49 \\
\text { rs17999371 } \\
T>C\end{array}$} \\
\hline & $\begin{array}{c}\text { rs22344582 }{ }^{1} \\
G>T \\
\text { (-7 from first ATG) }\end{array}$ & $\begin{array}{c}\text { rs1799925 } \\
\text { C>T } \\
\text { (Pro42Pro) }\end{array}$ & $\begin{array}{c}23857703^{2} \\
\text { G>A } \\
\text { (Pro54Pro) }\end{array}$ & & \\
\hline 1 & $T / T$ & $\mathrm{C} / \mathrm{C}$ & $\mathrm{A} / \mathrm{A}$ & $\mathrm{A} / \mathrm{A}$ & $\mathrm{C} / \mathrm{C}$ \\
\hline 2 & $T / T$ & $\mathrm{C} / \mathrm{C}$ & $\mathrm{G} / \mathrm{G}$ & $A / G$ & $T / T$ \\
\hline 3 & G/G & $\mathrm{T} / \mathrm{T}$ & G/G & G/G & $\mathrm{C} / \mathrm{C}$ \\
\hline 4 & $T / T$ & $T / T$ & $\mathrm{G} / \mathrm{G}$ & $A / G$ & $\mathrm{C} / \mathrm{C}$ \\
\hline 5 & $T / T$ & $\mathrm{C} / \mathrm{C}$ & $\mathrm{G} / \mathrm{G}$ & $A / G$ & $\mathrm{C} / \mathrm{C}$ \\
\hline 6 & $T / T$ & $T / T$ & $\mathrm{G} / \mathrm{G}$ & $\mathrm{A} / \mathrm{A}$ & $T / T$ \\
\hline 7 & $T / T$ & $\mathrm{C} / \mathrm{C}$ & $\mathrm{G} / \mathrm{G}$ & $\mathrm{G} / \mathrm{G}$ & $T / T$ \\
\hline 8 & $T / T$ & $\mathrm{C} / \mathrm{C}$ & $\mathrm{A} / \mathrm{A}$ & $\mathrm{G} / \mathrm{G}$ & $T / T$ \\
\hline 9 & $T / T$ & $\mathrm{C} / \mathrm{C}$ & A/A & $\mathrm{A} / \mathrm{A}$ & $T / T$ \\
\hline 10 & $\mathrm{G} / \mathrm{G}$ & $T / T$ & $\mathrm{G} / \mathrm{G}$ & $A / A$ & $T / T$ \\
\hline Normal male control & $T / T$ & $\mathrm{C} / \mathrm{C}$ & $\mathrm{G} / \mathrm{G}$ & $A / G$ & $T / T$ \\
\hline
\end{tabular}

${ }^{1} \mathrm{rs}=$ reference sequence number according to http://www.ncbi.nIm.nih.gov/SNP (20). ${ }^{2}$ Numbering according to $H$. sapiens chromosome 11 genomic contig (gil29807454IrefINT_009237.15IHs11_9394[29807454] http://www.ncbi.nlm.nih.gov/ (21). 
non-affected male siblings (8). Both mutations are located in the non-high motility group box, while the third one $(\mathrm{Y} 129 \mathrm{~N})$ is located at C-terminal of the high motility group box sequence (24). In vitro studies revealed that R30I mutant protein was poorly phosphorylated and showed reduced DNAbinding capacity (7), while the Y129N mutant exhibited altered protein-protein interactions (24). In addition, a case of XY partial gonadal dysgenesis with a de novo interstitial deletion at the 3' end of the SRYORF was reported by McElreavey et al. (25), who proposed that this deletion could be responsible for the abnormal gonadal development by diminishing $S R Y$ expression.

To date, no nucleotide changes in the $5^{\prime}$ UTR flanking sequence of the SRY gene have been reported in XY partial gonadal dysgenesis. A paternally inherited 3-bp deletion in the SRY 5'UTR Sp1 binding site has been demonstrated in a 46,XY female with pure gonadal dysgenesis (Assumpção JG, Maciel-Guerra AT, Marques-de-Faria AP, Guerra Jr G, Scolfaro MR and De Mello MP, unpublished data). The patient's father had surgically corrected hypospadias and penoscrotal fusion as a child and other affected relatives with genital ambiguity have been reported in this family. These findings suggest that, although rare, $S R Y$ mutations should be screened in cases of partial gonadal dysgenesis, especially if familial recurrence of genital ambiguity is reported.

In the present study, analysis of the WT1 gene revealed the $\mathrm{D} 396 \mathrm{~N}$ deleterious mutation in one of the patients with unilateral Wilms' tumor (patient No. 10). This mutation had already been described in patients with Denys-Drash syndrome (26,27), being the third most frequent mutation reported in the Universal WT1 mutation database (28). According to Little and Wells (29), the DenysDrash phenotype often arises from the alteration of one allele by a missense point mutation, usually in the zinc finger binding domain of WT1. The second and third zinc finger regions, encoded by exons 8 and 9 , are considered to be hot spots for mutations in patients with typical Denys-Drash nephropathy (30). Based on experimental evidence, some investigators have claimed that the Denys-Drash syndrome mutations behave in a dominant-negative fashion $(27,31,32)$, while others have proposed that heterozygous point mutations cause functional loss of one WT1 allele; therefore, haploinsufficiency may be responsible for the phenotype (33).

The constitutional heterozygous missense D396N, identified in patient 10 described here, affects the third zinc finger region of the protein. It has been shown that D396N has a slightly reduced binding affinity for selected DNA sequences when compared with the wild-type WT1 (34). Thus, the clinical phenotype of Denys-Drash syndrome in our patient may be associated with a modest reduction in the DNA binding affinity of WT1, either in a near-haploinsufficiency condition or in a dominant-negative fashion. Moreover, the persistence of the Müllerian ducts in this patient may indicate a MIS gene deregulation, since WT1 is an essential factor for the transactivation of MIS promoter (35). Indeed, co-transfection experiments with several zinc finger mutant $W T 1 \mathrm{~s}$ (D396N included) with either $S O X 9$ or $S F 1$ failed to activate synergistically reporter constructs containing the MIS promoter (36). WT1 is also considered a key regulator of the visceral epithelial cells (podocytes) of the mature glomerulus function, by repressing or activating $P A X 2$ expression $(37,38)$ and binding to conserved elements within the Podocalyxin gene promoter (39). Reduced expression levels leading to impairment of the podocytes cause crescentic glomerulonephritis and mesangial sclerosis (40) and could explain the early manifestations of nephrotic syndrome in our patient, which began after surgical excision of a left-sided Wilms' tumor at the age of 12 months. In a retrospective study of 12 patients treated for 
WT1 gene-related disorders, Auber et al. (30) reported that in Denys-Drash syndrome patients, proteinuria occurred very early and diffuse mesangial sclerosis or mesangial hyperplasia was the cause of end-stage renal disease, in the presence of missense point mutations affecting the third zinc finger.

We were unable to demonstrate any pathogenic mutation after sequencing the $10 \mathrm{ex}$ ons and the corresponding flanking regions of the WT1 gene of patient 9 described in this paper, who also had a Wilms' tumor at age four but remained free of renal disease after 5 years of follow-up. However, neither a WT1 intragenic deletion nor mutations in the promoter region that could significantly affect the transcription rate were excluded in the present case. Baird et al. (27) reported a similar case of an atypical XY Denys-Drash syndrome female patient with Wilms' tumor and ambiguous genitalia, but no nephropathy or WT1 gene mutations, arguing that such cases raise the possibility of the existence of other genes which may also predispose to this clinical condition.

No WT1 mutations were detected in patients with partial gonadal dysgenesis without renal abnormalities or Wilms' tumor manifestations (patients 1 to 8). Among the five SNP identified in some of these patients, three can be found in the SNP database, with allelic frequencies obtained from samples of 90 individuals (20). For the WT1 SNP 10cated at -7 from the first ATG $(G>T)$, the "G" and " $T$ " allele frequencies are of 0.722 and 0.278 , respectively. An inverted rate was found for our patients, with the " $T$ " allele being the most frequent one (0.8) but the small size of our sample precludes any conclusion. The "C" and "T" allelic frequencies reported for the $W T 1$ SNP located at exon 1 are 0.711 and 0.289 , respectively. In our sample, the frequencies were of 0.6 and 0.4 for the " $C$ " and " $T$ " alleles, respectively. The third SNP (IVS9-49 T>C) has frequencies of 0.55 and 0.45 reported for the " $\mathrm{T}$ " and "C" alleles, respectively. The " $\mathrm{T}$ " and "C" allelic frequencies in our patients were of 0.6 and 0.4 , respectively. Two not yet described sequence variations were identified in the present study, possibly representing new polymorphisms if we take into account the genotypic variation observed in the patient sample. Although the pathogenic significance of WT1 SNPs is largely unknown, it is possible to propose that some haplotypes could play a role in the efficiency of mRNA processing or translation due to secondary structures.

Our results suggest that $W T 1$ gene mutations are not a common cause of $46, \mathrm{XY}$ partial gonadal dysgenesis in the absence of renal abnormalities or Wilms' tumor manifestations. In conclusion, although mutations in the two major genes required for male gonadal development account for a minority of cases of XY partial gonadal dysgenesis, genetic analysis of the WT1 gene should be performed in these patients looking for Wilms' tumor or nephropathy risk factor. This clearly indicates that mutations at other chromosomal loci should be investigated in order to elucidate these complex clinical situations.

\section{References}

1. Robboy SJ, Miller T, Donahoe PR, Jahre C, Welch WR, Haseltine FP, Miller WA, Atkins L \& Crawford JD (1982). Dysgenesis of testicular and streak gonads in the syndrome of mixed gonadal dysgenesis: perspective derived from clinicopathologic analysis of twenty-one cases. Human Pathology, 13: 700-716.

2. Rey RA, Belville C, Nihoul-Fekete C et al. (1999). Evaluation of gonadal function in 107 intersex patients by means of serum antimullerian hormone measurement. Journal of Clinical Endocrinology and Metabolism, 84: 627-631.

3. Stuchi-Perez EG, Lukas-Croisier C, De Castro M, Baptista MTM, Scolfaro MR, Marques-de-Faria AP, Hackel C, Maciel-Guerra AT \& Guerra Jr G (2000). Evaluation of the tubular and the interstitial functions of the testis in 46,XY patients with ambiguous genitalia. Journal of Pediatric Endocrinology and Metabolism, 13: 605-612. 
4. Berkovitz GD, Fechener MD, Zacur HW, Rock JÁ, Snyder III MD, Migeon CJ \& Perlman EJ (1991). Clinical and pathologic spectrum of $46, X Y$ gonadal dysgenesis: its relevance to the understanding of sex differentiation. Medicine, 10: 375-383.

5. Scolfaro MR, Cardinalli IA, Gabas Stuchi-Perez E, De Mello MP, Assumpção JG, Baptista MTM, Silva JMB, Maciel-Guerra AT \& Guerra Jr G (2001). Morphometry and histology of gonads from 13 children with dysgenetic male pseudohermaphroditism. Archives of Pathology and Laboratory Medicine, 125: 652-656.

6. MacLaughlin DT \& Donahoe PK (2004). Sex determination and differentiation. New England Journal of Medicine, 350: 367-378.

7. Uehara S, Hashiyada M, Sato K, Nata M, Funato T \& Okamura K (2002). Complete $X Y$ gonadal dysgenesis and aspects of the SRY genotype and gonadal tumor formation. Human Genetics, 47: 279284.

8. Assumpção JG, Benedetti CE, Maciel-Guerra AT, Guerra Jr G, Baptista MTM, Scolfaro MR \& De Mello MP (2002). Novel mutations affecting SRY DNA-binding activity: the HMG box N65H associated with $46, X Y$ pure gonadal dysgenesis and the familial nonHMG box R30l associated with variable phenotypes. Journal of Molecular Medicine, 80: 782-790.

9. Poulat F, Desclozeaux M, Tuffery S, Jay P, Boizet B \& Berta P (1998). Mutation in the $5^{\prime}$ noncoding region of the SRY gene in an XY sex-reversed patient. Human Mutation, 1 (Suppl 1): S192-S194.

10. Matsuzawa-Watanabe $Y$, Inoue J \& Semba K (2003). Transcriptional activity of testis-determining factor $S R Y$ is modulated by the Wilms' tumor 1 gene product, WT1. Oncogene, 22: 5956-5960.

11. Shimamura R, Fraizer GC, Trapman J, Lau IC \& Saunders GF (1997). The Wilms' tumor gene WT1 can regulate genes involved in sex determination and differentiation: SRY, Müllerian-inhibiting substance, and the androgen receptor. Clinical Cancer Research, 3: 2571-2580.

12. Heathcott RW, Morison IM, Gubler MC, Corbett R \& Reeve AE (2002). A review of the phenotypic variation due to the Denys-Drash syndrome-associated germline WT1 mutation R362X. Human Mutation, 19: 462.

13. Wagner KD, Wagner N \& Schedl A (2003). The complex life of WT1. Journal of Cell Science, 116: 1653-1658.

14. Pritchard-Jones K, Fleming S, Davidson D et al. (1990). The candidate Wilms' tumour gene is involved in genitourinary development. Nature, 346: 194-197.

15. Fuqua JS, Sher ES, Perlman EJ, Urban MD, Ghahremani M, Pelletier J, Migeon CJ, Brown TR \& Berkovitz GD (1996). Abnormal gonadal differentiation in two subjects with ambiguous genitalia, Müllerian structures, and normally developed testes: evidence for a defect in gonadal ridge development. Human Genetics, 97: 506-511.

16. Quigley CA, De Bellis A, Marschke KB, el-Awady MK, Wilson EMD \& French FS (1995). Androgen receptor defects: historical, clinical, and molecular perspectives. Endocrine Reviews, 16: 271-321.

17. Sambrook J, Fristsch EF \& Maniatis TE (1989). Molecular Cloning: A Laboratory Manual. Cold Spring Harbor Press, Cold Spring Harbor, NY, USA.

18. Hawkins JR, Taylor A, Berta P, Levilliers J, Van der Auwera B \& Goodfellow PN (1992). Mutational analysis of SRY: nonsense and missense mutations in XY sex reversal. Human Genetics, 88: 471474.

19. Schmitt-Ney M, Thiele H, Kaltwasser P, Bardoni B, Cisternino M \& Scherer G (1995). Two novel SRY missense mutations reducing DNA binding identified in $X Y$ females and their mosaic fathers. American Journal of Human Genetics, 56: 862-869.

20. Single Nucleotide Polymorphism Database - dbSNP. http://
www.ncbi.nlm.nih.gov/SNP/index.html. Accessed November 28, 2003.

21. National Center for Biotechnology Information Nucleotide Database. http://www.ncbi.nlm.nih.gov/. Accessed September 12, 2003

22. Hawkins JR, Taylor A, Goodfellow PN, Migeon CJ, Smith KD \& Berkovitz GD (1992). Evidence for increased prevalence of SRY mutations in $\mathrm{XY}$ females with complete rather than partial gonadal dysgenesis. American Journal of Human Genetics, 51: 979-984.

23. Domenice S, Nishi MY, Billerbeck AEC et al. (1998). A novel missense mutation (S18N) in the $5^{\prime}$ non-HMG box region of the SRY gene in a patient with partial gonadal dysgenesis and his normal male relatives. Human Genetics, 102: 213-215.

24. Baud S, Margeat E, Lumbroso S, Paris F, Sultan C, Royer C \& Poujol $N$ (2002). Equilibrium binding assays reveal the elevated stoichiometry and salt dependence of the interaction between full-length human sex-determining region on the $\mathrm{Y}$ chromosome (SRY) and DNA. Journal of Biological Chemistry, 277: 18404-18410.

25. McElreavey K, Vilain E, Barbaux S et al. (1996). Loss of sequences $3^{\prime}$ to the testis-determining gene, $S R Y$, including the Y pseudoautosomal boundary associated with partial testicular determination. Proceedings of the National Academy of Sciences, USA, 93: 85908594.

26. Pelletier J, Bruening W, Kashtan CE et al. (1991). Germline mutations in the Wilms' tumor suppressor gene are associated with abnormal urogenital development in Denys-Drash syndrome. Cell, 67: 437-447.

27. Baird PN, Santos A, Groves N, Jadresic L \& Cowell JK (1992). Constitutional mutations in the WT1 gene in patients with DenysDrash syndrome. Human Molecular Genetics, 1: 301-305.

28. Jeanpierre C, Béroud C, Niaudet P \& Junien C (1998). Software and database for the analysis of mutations in the human WT1 gene. Nucleic Acids Research, 26: 271-274.

29. Little M \& Wells C (1997). A clinical overview of WT1 gene mutations. Human Mutation, 9: 209-225.

30. Auber F, Lortat-Jacob S, Sarnacki S, Jaubert F, Salomon R, Thibaud E, Jeanpierre C \& Cihoul-Fékété C (2003). Surgical management and genotype/phenotype correlations in WT1 gene-related diseases (Drash, Frasier syndromes). Journal of Pediatric Surgery, 38: 124129.

31. Bardeesy N, Zabel B, Schmitt K \& Pelletier J (1994). WT1 mutations associated with incomplete Denys-Drash syndrome define a domain predicted to behave in a dominant-negative fashion. Genomics, 21: 663-665.

32. Moffet $P$, Bruening $W$, Nakagama $H$, Bardeesy N, Housman $D$, Housman DE \& Pelletier J (1995). Antagonism of WT1 activity by protein self-association. Proceedings of the National Academy of Sciences, USA, 92: 11105-11109

33. Hossain A \& Saunders GF (2001). The human sex-determining gene SRY is a direct target of WT1. Journal of Biological Chemistry, 18: 16817-16823.

34. Borel F, Barilla KC, Hamilton TB, Iskandar M \& Romaniuk PJ (1996). Effects of Denys-Drash syndrome point mutations on the DNA binding activity of the Wilms' tumor suppressor protein WT1. Biochemistry, 35: 12070-12076

35. Nachtigal MW, Hirokawa Y, Enyeart-VanHouten DL, Flanagan JN, Hammer GD \& Ingraham H (1998). Wilms' tumor 1 and Dax-1 modulate the orphan nuclear receptor SF-1 in sex-specific gene expression. Cell, 93: 445-454.

36. Hossain A \& Saunders GF (2003). Role of Wilms' tumor 1 (WT1) in the transcriptional regulation of the Müllerian-Inhibiting Substance Promoter. Biology of Reproduction, 69: 1808-1814. 
37. Favor J, Sandulache R, Neuhauser KA et al. (1996). The mouse Pax2 ( $1 \mathrm{Neu}$ ) mutation is identical to a human PAX2 mutation in a family with renal-coloboma syndrome and results in developmental defects of the brain, ear, eye and kidney. Proceedings of the National Academy of Sciences, USA, 93: 13870-13875.

38. Ryan G, Steele Perkins V, Morris JR, Rauscher FJ \& Dressler GR (1995). Repression of Pax-2 by WT1 during normal kidney development. Development, 121: 867-875.

39. Palmer RE, Kotsianti A, Cadman B, Boyd T, Gerald W \& Haber DA
(2001). WT1 regulates the expression of the major glomerular podocyte membrane protein Podocalyxin. Current Biology, 11: 18051809.

40. Guo JK, Menke AL, Gubler MC, Clarke AR, Harrison D, Hammes A Hastie ND \& Schedl A (2002). WT1 is a key regulator of podocyte function: reduced expression levels cause crescentic glomerulonephritis and mesangial sclerosis. Human Molecular Genetics, 11: 651-659. 